\title{
PERBEDAAN PENGARUH PEMBERIAN JUS TOMAT DENGAN JUS BELIMBING MANIS TERHADAP TEKANAN DARAH PADA PENDERITA HIPERTENSI
}

\author{
Eka Febriani ${ }^{1}$, Siti Zulfah ${ }^{2}$ \\ 1,2 Jurusan Gizi, Politeknik Kesehatan Kemenkes Aceh, JL. Soekarno Hatta, Kampus Terpadu Poltekkes \\ Kemekes Aceh RI Aceh Lampeneurut, Aceh Besar. Telp.065146126. kode pos 23352
}

\begin{abstract}
ABSTRAK
Hipertensi merupakan penyakit darah tinggi yang sering dijumpai di kalangan masyarakat. Secara visual penyakit ini tidak tampak, hipertensi bisa membuat penderita terancam jiwanya. Upaya dalam menurunkan tekanan darah adalah dengan meningkatkan konsumsi kalium sepeti jus tomat dan jus belimbing manis. Tujuan penelitian melihat pengaruh perbedaan pemberian jus tomat dengan jus belimbing manis terhadap tekanan darah pada penderita hipertensi. Penelitian ini bersifat deskriptif analitik dengan desain penelitian Quasi Experimental yaitu untuk melihat perbedaan pengaruh tekanan darah sebelum dan sesudah diberikan jus tomat dengan jus belimbing manis dan diperoleh 32 orang. Penelitian ini dilakukan pada bulan Agustus 2013 di kecamatan Kota Jantho Aceh Besar. Data yang diambil yaitu data primer dan sekunder. Pengumpulan data dengan cara wawancara dengan menggunakan kuesioner. Analisa data dengan menggunakan uji T-Test independen pada derajat kepercayaan 95\%. Rerata penurunan tekanan darah sesudah pemberian jus tomat 147,81 mmHg (sistolik) dan 77,81 mmHg (diastolik), sedangkan rerata penurunan tekanan darah sesudah pemberian jus belimbing manis $135,38 \mathrm{mmHg}$ (sistolik) dan 80,88 $\mathrm{mmHg}$ (diastolik). Rerata perbedaan penurunan tekanan darah sesudah pemberian jus tomat turun sebesar 9,75 (sistolik) dan 9,94 (diastolik), sedangkan rerata perbedaan penurunan tekanan darah sesudah pemberian jus belimbing manis turun sebesar 20,19 (sistolik) dan 13,44 (diastolik). Ada pengaruh yang signifikan pemberian jus tomat dengan jus belimbing manis terhadap penurunan tekanan darah, $P=0,000(P \leq 0,05)$.
\end{abstract}

Kata Kunci : Hipertensi, Tekanan Darah, Juice Belimbing dan Tomat

\begin{abstract}
Hypertension is high blood pressure that is often found in the community. Visually, the disease does not appear, hypertension can make people threatened his life. Efforts to lower blood pressure by increasing potassium consumption crate of tomato juice and sweet starfruit juice. The research objective look at the effect of administration of tomato juice with sweet starfruit juice on blood pressure in patients with hypertension. This research is descriptive analytic design Quasi Experimental research is to see the difference in the effect of blood pressure before and after tomato juice with sweet starfruit juice and obtained 32 votes. This research was conducted in August 2013 in the district jantho. Data taken, namely primary and secondary data. Data collection by interview using a questionnaire. Test data analysis using independent T-Test on the degree of confidence of $95 \%$. The mean reduction in blood pressure after the administration of tomato juice $147.81 \mathrm{mmHg}$ (systolic) and $77.81 \mathrm{mmHg}$ (diastolic), while the average reduction in blood pressure after giving a sweet starfruit juice 135.38 $\mathrm{mmHg}$ (systolic) and $80.88 \mathrm{mmHg}$ (diastolic). The mean difference in blood pressure reduction after the administration of tomato juice decreased by 9.75 (systolic) and 9.94 (diastolic), whereas the mean difference in reduction of blood pressure after giving a sweet starfruit juice decreased by 20.19 (systolic) and 13.44 (diastolic ). There was a significant effect giving tomato juice with sweet starfruit juice on blood pressure reduction, $P=$ $0.000(P \leq 0,05)$.
\end{abstract}

Keywords : Hypertension, Blood Pressure, Starfruit and Tomato Juice

AcTion Journal, Volume 1, Nomor 1, Mei 2016 